(27)埋設構造物の液状化挙動に関する有効応力解析

一振動台実験との比較一

$\begin{array}{rlr}\text { 大林組技術研究所 } & \text { 正会員 } & \text { ○松田 隆 } \\ & \text { 正会員 } & \text { 伊藤 浩二 } \\ & \text { 正会員 鳥井原 誠 }\end{array}$

\title{
1.はじめに
}

動的有効応力解析法は詳細な地震時液状化挙動の把握手法として用いられている。ただし、提案されてい る動的有効応力解析法の多くは 1 次元あるいは 2 次元の領域を対象としており、奥行き方向に一様でない構 造物を対象とする場合の 3 次元性が考慮できないのが現状である。また、震動方向に関しても実地震での任 意空間成分を考慮するためにも 3 次元性を導入する必要がある。そこで、著者らは多方向入力が可能な 3 次 元動的有効応力解析法（"EFECT" と称す）の開発を行ない、その適用性を検討してきた。

ここで開発した"EFECT"には松岡により提案された 2 次元応力下の構成モデルに弾性ひずみ成分を加え、 更に、その構成関係を 3 次元空間に拡張した手法を導入している。これまで、このモデルに対して応力経路 の異なる種々の要素試験や波浪荷重による線形応答などを対象として検証を行ってきた。今回は、構造物と 地盤の相互作用系における本手法の適用性を検討するため、飽和地盤中に埋設された構造物の液状化時挙動 に関する振動台加振実験を対象とした"EFECT" の解析を実施した。この報告では、地盤の応答加速度・過剩 間隙水圧の経時変化や構造物の永久変位量に関して実験結果と解析結果、および、2 次元解析結果と 3 次元

解析結果を比較する。

\section{2. 振動台実験}

実験の対象となる構造物は $1 / 8$ に縮小した $20 \mathrm{k} 1$ 級コンクリート被覆貯油槽であ る（図 1 ）。空液時模型眝油槽の見かけの比重 1.4 は地盤の飽和重量 $1.9 \mathrm{t} / \mathrm{m}^{3}$ の $3 / 4$ になるよう調整したもので、液状化時には浮き上がる構造 である。振動台上の模型地盤は大型せん断土槽に保持されており、模型地 盤の諸特性は表 1 に示す通りである。この時の相対密度は $46 \%$ である。軽 量埋設構造物の大きさは模型地盤の寸法に比べ充分小さいため、地盤の非 排水境界の影響は小さいと考えられる。地下水位と模型貯油槽上面は地表 面位置に設定した。

振動台への入力は一方向とし、時間軸を $1 / 4$ に 縮小した八戸波（継続時間10.4秒）で最大加速度 115galに設定した。

\section{3. 解析手法}

動的有効応力解析法 "EFECT"は 3 次元空間での U-u 形式によるBiotの釣合い式に基づいている。構 成式の基本は松岡モデルであり、非線形解法は初期 剛性法によっている。松岡モデルでは 2 主応力平面 における塑性ひずみ増分をせん断、主応力の回転、 異方及び等方圧密の総和で与えているが、ここでは 初期剛性法の適用上、弾性ひずみ成分を加えている

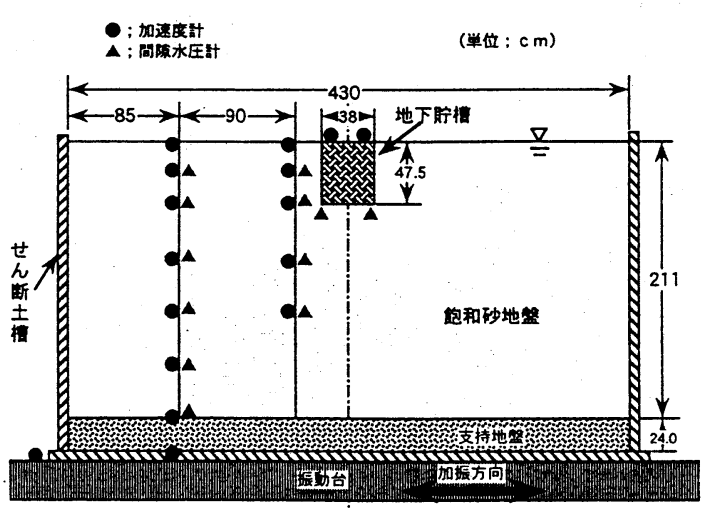

図 2 模型地盤と計器配置 
（式-1）。3 次元への拡張は C M P 理論（複合滑動面）に基づき、各主応力平面上での値を加えあわせるこ とで評価した。このとき、等方圧密成分は 3 主応力方向に等しく生じ、弾性成分は通常の弾性応力〜ひずみ 関係 $\mathrm{D}^{\mathrm{E}}$ より評価した。

$$
\begin{aligned}
& \left\{d \varepsilon_{i j}\right\}=\left\{d \varepsilon_{i j}{ }_{i j}+\sum_{k=1}^{3}\left[\left\{d \varepsilon^{P_{s}}\right\}_{K}+\left\{d \varepsilon^{P_{R}}\right\}_{k}+\left\{d \varepsilon^{P_{A C}}\right\}_{k}\right]+\left\{d \varepsilon^{P_{I C}}\right\}\right. \\
& \left\{d \sigma_{i j}\right\}=\left[D^{E}\right] \quad\left\{d \varepsilon_{i j}{ }^{E}\right\}
\end{aligned}
$$

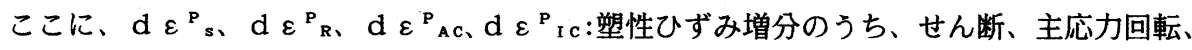

\section{異方及び等方圧密の各成分}

$\mathrm{k}$ : 主応力平面

$D^{E} 、 d \varepsilon_{i j}{ }^{E}:$ 弾性の応力〜ひずみ関係、弾性ひずみ成分

\section{4. 解析方法}

加振方向の解析対象領域は自由地盤とみなせ る構造物から $70 \mathrm{~cm}$ 離れた位置までとした。加振 直角方向は対称性を考慮し全領域の $1 / 2$ である

（図 3 ）。境界は側面を繰り返し境界、底面を固 定境界にした。

地盤の諸入力定数（表 2 ）のうち、非線形構成 則に関連するものは低拘束圧下での三軸試験を基 に設定した。また、弾性係数など微小ひずみ領域 の特性に関するものは表 1 に示す地表面での微動 測定結果の卓越振動数から設定している。

\section{5. 実験結果と解析結果の比較}

図 4 に応答加速度と過剩間隙水圧の経時変化を 示す。最大加速度に関しては解析のほうが大きい 振幅值を示しているが、位相特性や間隙水圧の上 昇に伴う周期の伸びなどに関して解析結果は実験 結果を追随している。振幅に関しても、液状化し たと考えられる 3.5 秒以降加速度 は増幅しないが、解析でもその傾 向は再現できている。

自由地盤側の過剩間隙水圧 (P1、 P2）に関しては最大值および最大 值に達する時刻など、解析と実験 の一致が認められる。

貯油槽側面の過剩間隙水圧P4で は解析は実験のほほ $3 / 5$ 程度しか でていない。これに対して、底面 の過㮃間隙水圧P3は解析のほうが 大きくなっている。これは、実験 では過剩間隙水圧が急激に上昇す

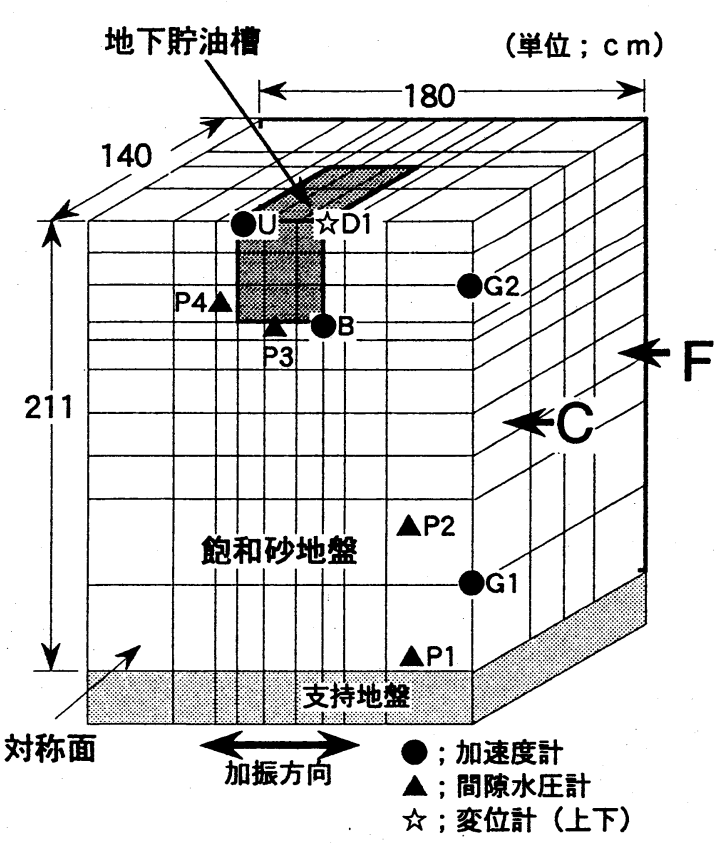

図3 要素分割

\begin{tabular}{|c|c|c|}
\hline \multicolumn{2}{|c|}{ 土粒子比重 } & 2.65 \\
\hline \multicolumn{2}{|c|}{$\begin{array}{l}\text { 平均的な } \\
\text { 単位体積重量 }\end{array}$} & $\begin{array}{l}18.52 \\
\mathrm{kN} / \mathrm{m}^{3}\end{array}$ \\
\hline \multicolumn{2}{|c|}{1 次共振振動数 } & $7.90 \mathrm{~Hz}$ \\
\hline \multicolumn{2}{|c|}{ 初期間隙率 } & 0.461 \\
\hline \multicolumn{2}{|c|}{ 初期間隙比 } & 0.851 \\
\hline \multicolumn{2}{|l|}{ 均等係数 } & 1.36 \\
\hline \multicolumn{2}{|l|}{ 平均粒径 } & $0.325 \mathrm{~mm}$ \\
\hline \multirow{2}{*}{ 地盤領域 } & 平面 & $4.3 \mathrm{~m} \times 2.3 \mathrm{~m}$ \\
\hline & 深度 & $2.11 \mathrm{~m}$ \\
\hline
\end{tabular}

表 1 模型地盤特性

\begin{tabular}{|c|c|}
\hline 硬化バラメー夕ー $\mathrm{k}_{\mathrm{s}}$ & 0.0006 \\
\hline $\begin{array}{ll}\text { 多イ侈ソシ } & \lambda \\
\text { イラメータ- } & \mu\end{array}$ & $\begin{array}{l}1.2 \\
0.28\end{array}$ \\
\hline 圧縮 指 数 $\mathrm{C}_{\mathrm{c}}$ & 0.022 \\
\hline 膨張指数 $\mathrm{C}_{\mathrm{s}}$ & 0.011 \\
\hline 非共軸ハラメー夕ー $\delta$ & $30^{\circ}$ \\
\hline 骨格弾性係数 E & $21000 \mathrm{kPa}$ \\
\hline ポアソン比 $\nu$ & 0.33 \\
\hline 透水係数 $\mathrm{k}$ & $10^{-5} \mathrm{~m} / \mathrm{sec}$ \\
\hline$\nu-リ$-減衰係数 $\beta$ & 0.01 \\
\hline
\end{tabular}

表 2 入力定数 

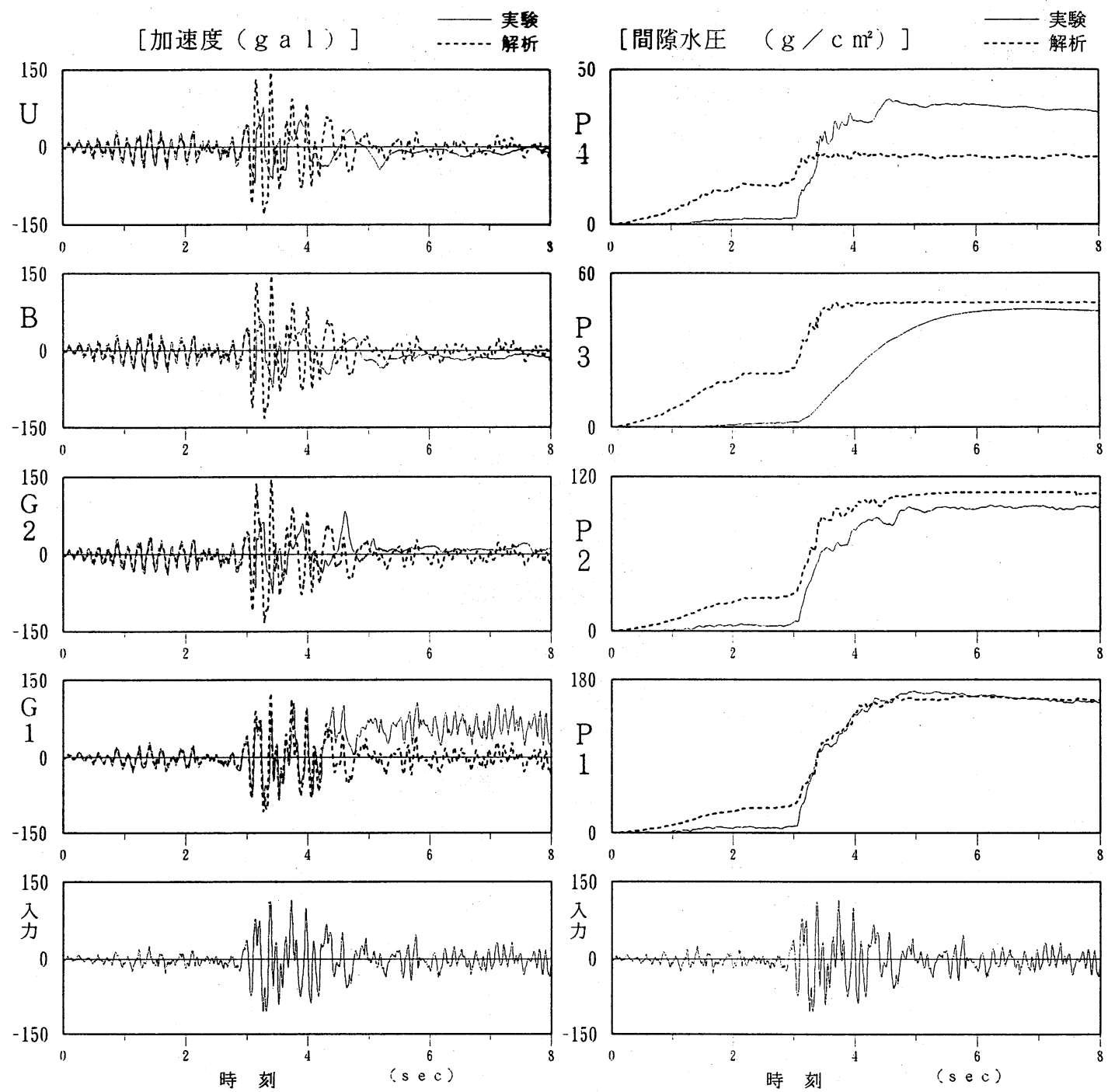

図4 加速度および過剩間隙水圧の経時変化

る時刻から眝油槽の浮上D1が始まり、その影響 で貯油槽底部の過剩間隙水圧が大きく低下した と考えられる。この点、解析での眝油槽の浮上 量D(図 5 ) は実験值のほぼ $1 / 3$ しか出ておら ず、そのため解析でのP3過剩間隙水圧の低下は あまりみられなかったと考えられる。貯槽の浮 上量Dに関しては、実験時の貯油槽と地盤は地 盤の液状化にともなう不連続状態、すなわち滑 りだすのに対して、解析はこの部分の不連続性 をモデル化していなかったことに差を生じさせ た原因がある。

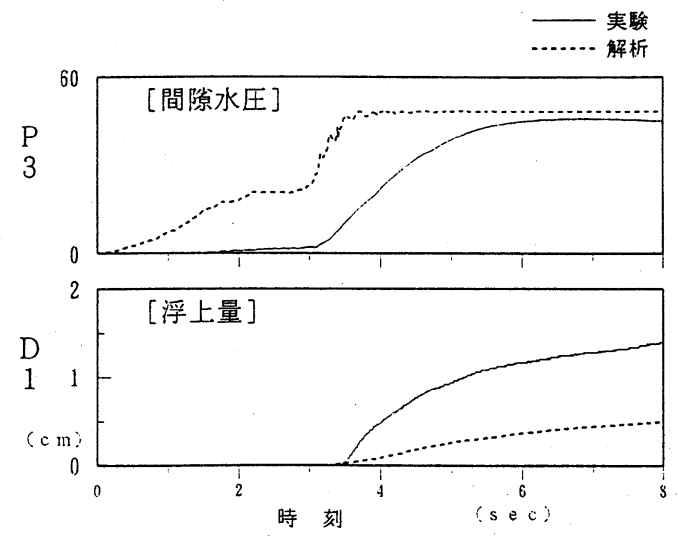

図 5 貯槽の浮上量 
貯槽周辺の液状化挙動に関して、解析上 2 次元と 3 次元を比較した結果を図 6 に示す。過剩間隙水圧に関 しては最大值はほぼ同様であるが、初期動部分において 3 次元の方が大きくなっている。これは、3次元の 方が加振直角方向のひずみを加えあわせ間隙水圧の上昇を考慮しているためである。加速度については 3 次 元の方が小さく、2 次元とは最大值で $15 \%$ 程度の差が生じている。これは間隙水圧の上昇に伴う地盤剛性の 低下に関連しており、間隙水圧の上昇がより大きい 3 次元の方が剛性低下が大きく、その結果、振幅が小さ くなる傾向になる。

図 7 に過剩間隙水圧比の分布を示す。地盤の上方から液状化が始まること、構造物の背面でも液状化が進 展していることが分かる。

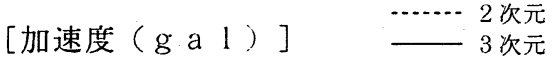

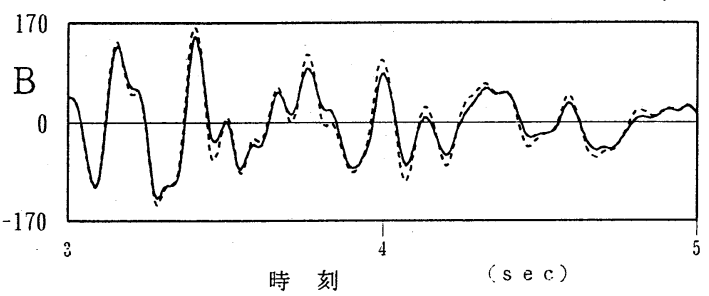

図6 2次元と 3 次元の比較

[ 2 秒後]
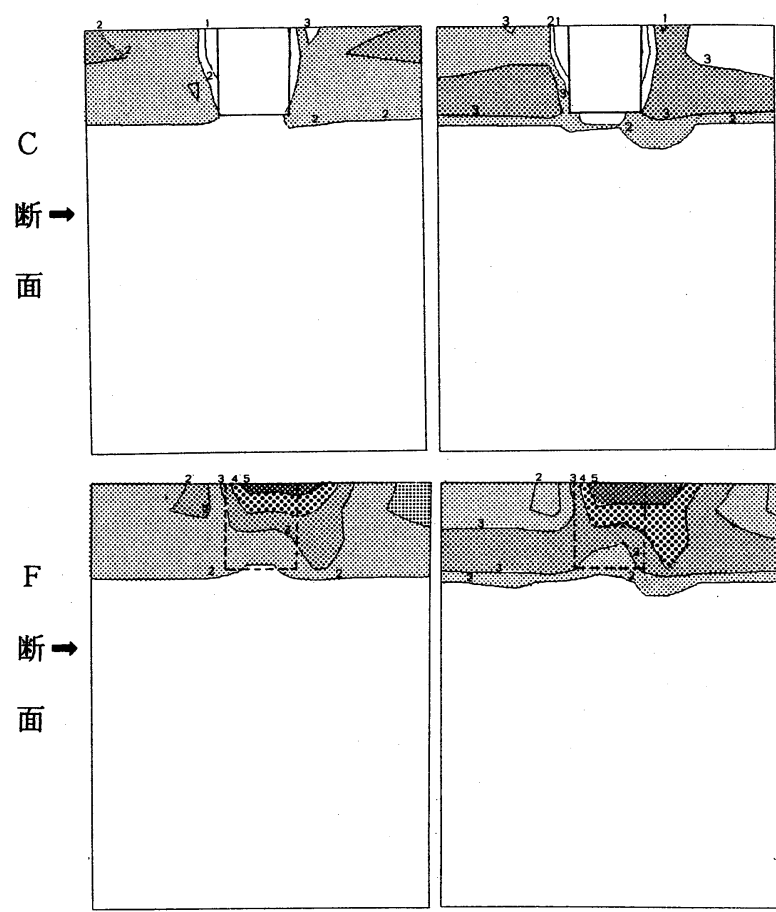

\section{5. まとめ}

地中構造物〜飽和地盤相互作用系の振動台実験を対象としたシシュレショョ解析を行なった。その結果、動的有 効応力解析法EFECT は過剩間隙水圧の経時変化や液状化時の応答加速度の減衰など実験結果を良好に再現で きることが確認できた。また、地中構造物の液状化挙動も定性的に表現できることが分かった。 参考文献 : 伊藤ほか (1992)；3 次元応力下の砂の綝り返しせん断挙動の解析、第27土質工学研究発表会1101
[ 8 秒後]

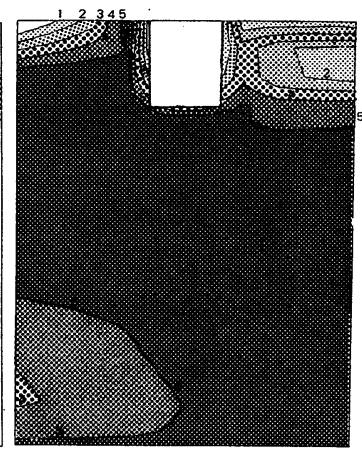

過剩間隙水圧比

凡例

$: 0.6 \sim 0.8$

$: 0.8 \sim 1.0$

$: 1.0$ 液状化

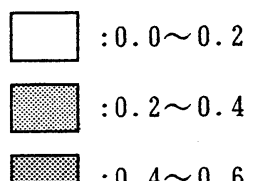

図7過剩間隙水圧の分布 